\title{
Removal of Heavy Metals with Membrane Bioreactor Combined with Activated Carbon
}

S. Çalık ${ }^{1}$, E. Özgenç ${ }^{1}$, A.E. Yılmaz ${ }^{1}$, O. Sozudogru ${ }^{1}$, T.M. Massara ${ }^{2,3}$, E. Katsou ${ }^{2,3}$, O.T. Komesli ${ }^{1}$

${ }^{1}$ Department of Environmental Engineering, Faculty of Engineering, Ataturk University, 25240, Erzurum, Turkey.

${ }^{2}$ Institute of Environment, Health and Societies, Brunel University London, Uxbridge Campus, Middlesex, UB8 3PH, Uxbridge, UK.

${ }^{3}$ Department of Mechanical, Aerospace and Civil Engineering, Brunel University London, Uxbridge Campus, Middlesex, UB8 3PH, Uxbridge, UK.

Corresponding Author: Evina Katsou (Evina.Katsou@ brunel.ac.uk; Tel.: +44 (0)1895 265721) 


\begin{abstract}
In this study, the removal of selected heavy metals (nickel $(\mathrm{Ni})$, lead $(\mathrm{Pb})$, arsenic (As) and zinc $(\mathrm{Zn})$ ) by a lab-scale submerged membrane bioreactor (MBR) combined with a granular activated carbon (GAC) system was investigated. Different membrane fluxes (16, 20 and $24 \mathrm{~L} \mathrm{~m}^{-2} \mathrm{~h}^{-1}$ ) and hydraulic retention times (HRTs: $12.8 \mathrm{~h}, 10.4 \mathrm{~h}$ and $9.2 \mathrm{~h}$ ) were applied as variable parameters to examine how they influence removal efficiency. Synthetically prepared wastewater was pre-treated in the MBR. Then, the efficiency of GAC adsorption applied as post-treatment was additionally examined in the current study. Chemical oxygen demand (COD), ammonium $\left(\mathrm{NH}_{4}-\mathrm{N}\right)$ and phosphates $\left(\mathrm{PO}_{4}-\mathrm{P}\right)$ were measured in two phases: first, after the MBR treatment step and, secondly, after the GAC posttreatment. The highest heavy metal removal efficiency after the $1^{\text {st }}$ treatment stage (i.e. MBR effluent) was obtained at the lowest flux value (i.e. $16 \mathrm{~L} \mathrm{~m}^{-2} \mathrm{~h}^{-1}$ ). $\mathrm{Ni}, \mathrm{Pb}, \mathrm{Zn}$ and As removals were measured as equal to 96.9, 98.3, 98 and 8.5\%, respectively. Under the lowest applied flux value, $\mathrm{COD}, \mathrm{NH}_{4}-\mathrm{N}$ and $\mathrm{PO}_{4}-\mathrm{P}$ removals were also found to be the highest (96.8, 98.9 and 46\%, respectively) for the MBR effluent due to minimized heavy metal toxicity. More importantly, heavy metal concentration was under the limit of detection after the GAC post-treatment; over 99\% removal was achieved for all heavy metals.
\end{abstract}

Keywords: Heavy metal removal, membrane bioreactor, granular activated carbon, adsorption, flux

\begin{tabular}{ll}
\hline Nomenclature & \\
\hline CAS & Conventional Activated Sludge \\
\hline COD & Chemical Oxygen Demand \\
\hline GAC & Granular Activated Carbon \\
& \\
\hline ICP-MS & $\begin{array}{l}\text { Inductively Coupled Plasma Mass } \\
\text { Spectrometry }\end{array}$
\end{tabular}




\begin{tabular}{ll}
\hline HRT & Hydraulic Retention Time \\
\hline MBR & Membrane Bioreactor \\
\hline MLSS & Mixed Liquor Suspended Solids \\
\hline MLVSS & Mixed Liquor Volatile Suspended Solids \\
\hline PES & Polyethersulfone \\
\hline SRT & Sludge Retention Time \\
\hline TSS & Total Suspended Solids \\
\hline
\end{tabular}

\section{Introduction}

Water resources are becoming increasingly scarce. Thus, wastewater treatment is needed to enable water reuse in line with the concept of sustainable water resources management. More importantly, water quality standards in recent years are following highly stringent laws and regulations [1-2]. Heavy metals such as lead (Pb), nickel (Ni), arsenic (As) and zinc (Zn) traced in surface and underground waters are of the utmost importance due their impact on ecosystems and human health [3-4]. They are considered pollutants with significant direct and indirect effects even at very low concentrations $[2-5]$.

Heavy metal discharge occurs through effluents originating from various industrial sectors such as metallurgy, mining, electroplating plants, leather, nuclear and electronic industries, etc. [4, 6-7]. Living beings need a certain concentration of heavy metals to survive and perform their essential vital activities [8-10]. Even the low concentration of heavy metals existing within organisms is hardly biodegradable via natural processes and can only converted to less toxic forms $[5,11]$. If the heavy metal discharge to the receiving environment exceeds a certain concentration, it affects the food chain, the living beings and, thus, part or the whole ecosystem [12]. Hence, it is necessary that effluents including significant heavy metal concentration undergo a certain pretreatment prior to being 
discharged to the ecosystem. Domestic and industrial wastewaters are treated together in many wastewater treatment plants [13]. More effective and economical treatment alternatives have been developed, but the biological treatment has gained ground amongst them [14]. In terms of heavy metal removal from wastewater, various alternatives exist including ion exchange, adsorption [15], coagulation/flocculation [16], flotation [17], electrochemical precipitation [18], and membrane bioreactors (MBRs) [19].

MBRs are an attractive option widely applied both in industrial and municipal wastewater treatment as a very effective and successful technology [20]. Small carbon footprint, superior effluent quality, high biomass retention at high organic loading rates and high organic removal when compared to conventional activated sludge (CAS) systems are among their advantages [21-22]. They can also be used for the treatment of specific industrial wastewaters such as textile, leather etc. [23-25]. Heavy metal removal from wastewater by MBRs is usually associated with high Mixed Liquor Suspended Solids (MLSS) content and solid retention time (SRT) [13, 26-27]. Heavy metal removal by microorganisms is called biosorption [28]. During the biosorption, heavy metals are bound by living cells, dead biomass and extracellular polymeric substances [29]. However, the bounding occurs randomly. Moreover, heavy metal removal depends on the metal type and concentration. Binding heavy metals to biopolymers through biosorption can reduce toxicity and increase biological activity [30-31].

In the current study, a lab-scale MBR (pre-treatment) combined with granular activated carbon (GAC) (posttreatment) was implemented to investigate the removal of selected heavy metals (nickel $(\mathrm{Ni})$, lead $(\mathrm{Pb})$, arsenic $(\mathrm{As})$ and zinc (Zn)) from synthetic wastewater at 3 different flux values $\left(16,20\right.$ and $\left.24 \mathrm{~L} \mathrm{~m}^{-2} \mathrm{~h}^{-1}\right)$ and hydraulic retention times (HRTs: $12.8 \mathrm{~h}, 10.4 \mathrm{~h}$ and $9.2 \mathrm{~h}$ ).

\section{Materials and Methods}

\subsection{MBR and GAC system}

During the study, removal of selected heavy metals $(\mathrm{Ni}, \mathrm{Pb}$, As and $\mathrm{Zn}$ ) by a MBR followed by GAC was investigated. The system was divided into two parts. The first part was the MBR as shown in Fig.1. 


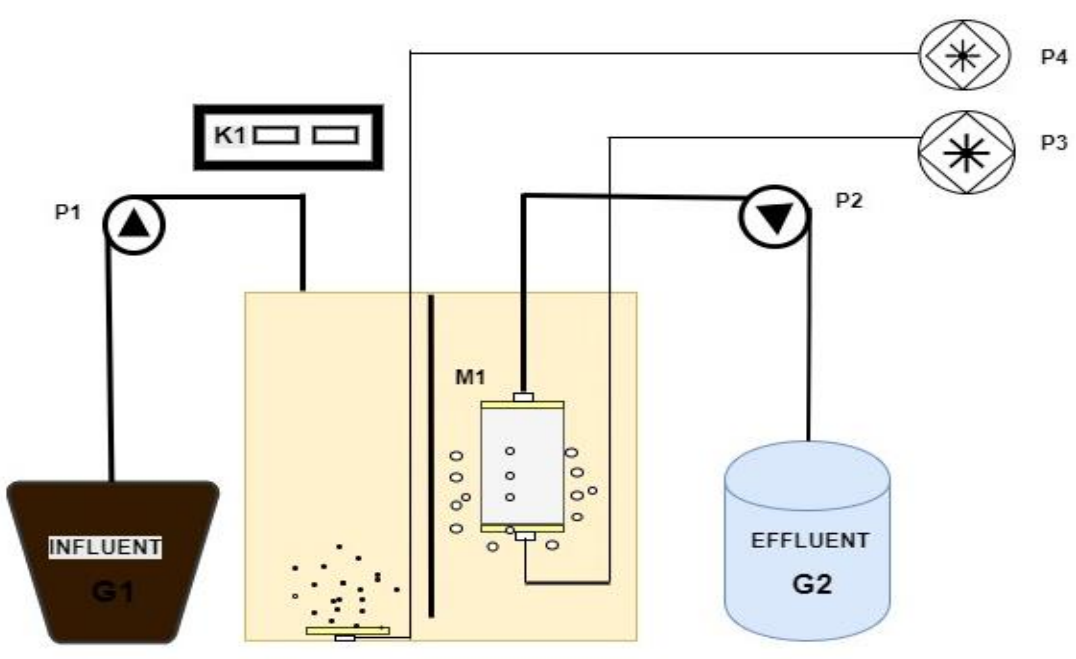

\begin{tabular}{ll}
\hline P1: feed pump & G1: influent \\
\hline P2: vacuum pump & G2: effluent \\
\hline P3: membrane & M1: fleet sheet membrane \\
blower & \\
\hline P4: air pump & K1: conductor \\
\hline
\end{tabular}

Figure 1. Process diagram of the MBR applied for the pre-treatment of synthetic wastewater.

The MBR was used for the pretreatment of the synthetic wastewater. The total volume of the lab-scale MBR tank was $20 \mathrm{~L}$. The tank was designed according to the principle of computational and divided into two sections to enable water flow from the bottom. The first section was aerated with the aid of an air pump (P4). In the second section, there was a membrane aerated with the aid of a diffuser (P3) to prevent fouling. Both tanks were inoculated with activated sludge collected from a full-scale municipal CAS plant in Erzurum (Turkey). A flat sheet membrane (M1) was placed in the 8 -L membrane chamber for solid-liquid separation. It was a plate and frame Polyethersulfone (PES) membrane with a pore size of $0.038 \mu \mathrm{m}$ (Fig. 1). The total area of each unit was $0.032 \mathrm{~m}^{2}$. In each period, the membrane module was cleaned using $500 \mathrm{mg} \mathrm{Cl}_{2} \mathrm{~L}^{-1}$ hypochlorite. The MLSS concentration in the membrane tank was approximately $4.5 \mathrm{~g} \mathrm{~L}^{-1}$ at the beginning of each cycle, and $12 \mathrm{~g} \mathrm{~L}^{-1}$ at the end of the cycle. Three different membrane fluxes were applied in the membrane unit by using a vacuum pump (P2); i.e. 16, 20 and $24 \mathrm{~L} \mathrm{~m}^{-2} \mathrm{~h}^{-1}$ for periods 1,2 and 3, respectively. Post treatment occurred by using GAC. Its properties are given below (Table 1).

Table 1. GAC properties. 


\begin{tabular}{ll}
\hline \multicolumn{1}{c}{ Activated Carbon Powder } \\
\multicolumn{1}{c}{ Specification } \\
\hline Density & $1.8-2.1 \mathrm{~g} \mathrm{~cm}^{-2}$ \\
\hline Solubility in water & Insoluble \\
\hline Molarity & $12.01 \mathrm{~g} \mathrm{~mol}^{-1}$ \\
\hline pH & $4-7$ \\
\hline CTC absorption & $62 \mathrm{~min}$ \\
\hline Bulk density & $0.42-0.52 \mathrm{~g} \mathrm{~mL}^{-1}$ \\
\hline Moisture content & $5 \%(\mathrm{max})$ \\
\hline Ash content & $4 \%(\mathrm{max})$ \\
\hline Iodine number & $1120 \mathrm{mg} \mathrm{g} \mathrm{min}^{-1}$ \\
\hline Hardness & $96 \%(\min )$ \\
\hline
\end{tabular}

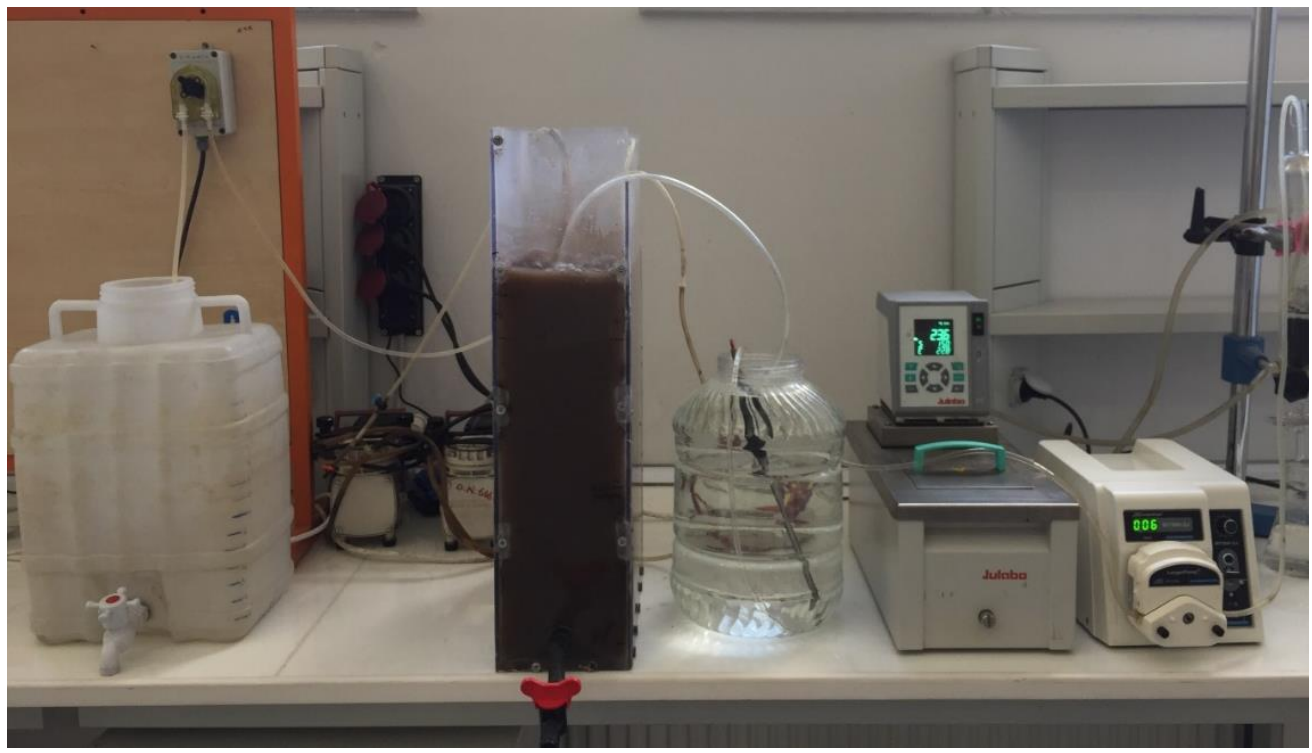

Figure 2. The whole lab-scale integrated treatment system used in the current study (MBR pre-treatment and GAC post-treatment).

\subsection{Synthetic wastewater characteristics}


COD in the influent ranged from 475.4 and $680.7 \mathrm{mg} \mathrm{L}^{-1}$ in all the runs. Table 2 shows the composition of the synthetic wastewater used in the current study. A stock solution containing the selected heavy metals $(\mathrm{Ni}, \mathrm{Pb}, \mathrm{As}$ and Zn) was prepared and added to the synthetic wastewater.

Table 2. Composition of the synthetic wastewater treated in the MBR.

\begin{tabular}{cc}
\hline Element & Concentration $\left(\mathbf{m g ~ L}^{-1}\right)$ \\
\hline $\mathrm{CH}_{3} \mathrm{COONa} .3 \mathrm{H}_{2} \mathrm{O}$ & 500 \\
\hline $\mathrm{NH}_{4} \mathrm{Cl}$ & 80 \\
\hline $\mathrm{KH}_{2} \mathrm{PO}_{4}$ & 18 \\
\hline $\mathrm{NaHCO}$ & 140 \\
\hline $\mathrm{Pb}$ & 0.2 \\
\hline $\mathrm{Ni}$ & 0.2 \\
\hline $\mathrm{As}$ & 0.2 \\
\hline $\mathrm{Zn}$ & 0.2 \\
\hline
\end{tabular}

\subsection{Sampling and analytical methods}

Samples were collected 4 times per week from the membrane effluent. Influent and effluent heavy metal $(\mathrm{Ni}, \mathrm{Pb}, \mathrm{As}$ and $\mathrm{Zn}$ ) concentration was continuously measured. Heavy metal analysis was carried out by inductively coupled plasma mass spectrometry (ICP-MS). The samples were measured for their chemical oxygen demand (COD), ammonium $\left(\mathrm{NH}_{4}-\mathrm{N}\right)$, nitrate $\left(\mathrm{NO}_{3}-\mathrm{N}\right)$ and phosphate $\left(\mathrm{PO}_{4}-\mathrm{P}\right)$ content. MLSS, mixed liquor volatile suspended solids (MLVSS), total suspended solids (TSS), $\mathrm{COD}$ and $\mathrm{NH}_{4}-\mathrm{N}$ were analyzed according to standard methods of analysis. The TSS were determined according to the 2540B Standard Method and the COD analysis was accomplished according to the 5220C Standard Method. Samples were filtered through Whatman membranes $(0.45 \mu \mathrm{m})$ and the filtrate was measured photometrically for its $\mathrm{NH}_{4}-\mathrm{N}, \mathrm{NO}_{3}-\mathrm{N}$ and $\mathrm{PO}_{4}-\mathrm{P}$ content using a Merck Pharo 300 spectrometer. $\mathrm{NH}_{4}-\mathrm{N}, \mathrm{NO}_{3}-\mathrm{N}$ and $\mathrm{PO}_{4}-\mathrm{P}$ analysis was succeeded by Merck kits $\left(\mathrm{NH}_{4}-\mathrm{N}\right.$ with no: $14752 ; \mathrm{NO}_{3}-\mathrm{N}$ with no: 09713 and $\mathrm{PO}_{4}-\mathrm{P}$ with no: 14842).

\section{Results}


The HRT decrease from 12.8 to $10.4 \mathrm{~h}$ caused a $25 \%$ increase in the membrane flux (from 16 to $20 \mathrm{~L} \mathrm{~m}^{-2} \mathrm{~h}^{-1}$ ). Removal of $\mathrm{Ni}, \mathrm{Zn}, \mathrm{Pb}, \mathrm{As}$ and COD decreased from $96.9 \%$ to $92.6 \%$, from 98 to $95 \%$, from 98.3 to $96.4 \%$, from 8.5

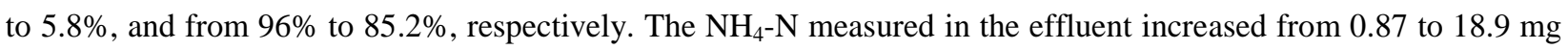
$\mathrm{L}^{-1}$ while the $\mathrm{NH}_{4}-\mathrm{N}$ removal decreased from 98.9 to $76.5 \%$. $\mathrm{PO}_{4}-\mathrm{P}$ concentration in the effluent was observed to rise from 11.7 to $20.4 \mathrm{mg} \mathrm{L}^{-1}$ translated into a decrease in the removal from 46 to $7 \%$. When the membrane flux was further increased to $24 \mathrm{~L} \mathrm{~m}^{-2} \mathrm{~h}^{-1}$, the removal of $\mathrm{Ni}, \mathrm{Zn}, \mathrm{Pb}$ and As further decreased to 92.2, 86.5, 95.8 and 1.4\%, respectively. COD removal dropped at $84.4 \%$ as microorganisms were exposed to heavy metal toxicity. $\mathrm{NH}_{4}-\mathrm{N}$ and $\mathrm{PO}_{4}-\mathrm{P}$ concentrations in the effluent were 31.7 and $24.5 \mathrm{mg} \mathrm{L}^{-1}$, respectively. $\mathrm{NH}_{4}-\mathrm{N}$ removal was $60.3 \%$ and $\mathrm{PO}_{4}-\mathrm{P}$ was found to be below 5\%. After GAC adsorption, all heavy metals' concentration was under the limit of detection.

\section{Conclusion}

During the study, the efficiency of a MBR (pre-treatment) combined with GAC (post-treatment) in removing selected heavy metals $(\mathrm{Ni}, \mathrm{Pb}, \mathrm{As}$ and $\mathrm{Zn}$ ) from synthetic wastewater was investigated at lab-scale for different flux

values $\left(16,20\right.$ and $\left.24 \mathrm{~L} \mathrm{~m}^{-2} \mathrm{~h}^{-1}\right)$. The highest heavy metal removal after the $1^{\text {st }}$ treatment stage (i.e. MBR effluent) was obtained at the lowest flux value (i.e. $16 \mathrm{~L} \mathrm{~m}^{-2} \mathrm{~h}^{-1}$ ). Ni, $\mathrm{Pb}, \mathrm{Zn}$ and As removals were measured as equal to 96.9, 98.3, 98 and 8.5\%, respectively. Under the lowest flux value, $\mathrm{COD}, \mathrm{NH}_{4}{ }^{+}-\mathrm{N}$ and $\mathrm{PO}_{4}{ }^{-3}-\mathrm{P}$ removals were also found to be the highest (96.8, 98.9 and $46 \%$, respectively) for the MBR effluent due to minimized heavy metal toxicity. After the GAC post-treatment, over 99\% removal was achieved for all heavy metals.

\section{Acknowledgements}

T.M. Massara is grateful to the Natural Environment Research Council (NERC) of the UK for the 4-year full PhD studentship.

\section{References}


[1] Chipasa, K.B.: Accumulation and fate of selected heavy metals in a biological wastewater treatment system.Waste Manage. 23 (2), 135-143 (2003)

[2] Fu, F., Wang, Q.: Removal of heavy metal ions from wastewaters: a review. J. Environ. Manage. 92 (3), 407-418 (2011)

[3] Min, X., Chai, L., Zhang, C., Takasaki, Y., Okura, T.: Control of metal toxicity, effluent COD and regeneration of gel beads by immobilized sulfate-reducing bacteria. Chemosphere 72 (7), 1086-1091 (2008)

[4] Kiran, M.G., Pakshirajan, K., Das, G.: A new application of anaerobic rotating biological contactor reactor for heavy metal removal under sulfate reducing condition. Chem. Eng. J. 321, 67-75 (2017)

[5] Carolin, C.F., Kumar, P.S., Saravanan, A., Joshiba, G.J., Naushad, M.: Efficient Techniques for the Removal of Toxic Heavy Metals from Aquatic Environment: A Review. J. Environ. Chem. Eng. In press (2017)

[6] Kikot, P., Viera, M., Mignone, C., Donati, E.: Study of the effect of $\mathrm{pH}$ and dissolved heavy metals on the growth of sulfate-reducing bacteria by a fractional factorial design. Hydrometallurgy 104 (3), 494-500 (2010)

[7] Gopi Kiran, M., Pakshirajan, K., Das, G.: Heavy Metal Removal Using Sulfate-Reducing Biomass Obtained from a Lab-Scale Upflow Anaerobic-Packed Bed Reactor. J. Environ. Eng. 142 (9), C4015010 (2015)

[8] Duruibe, J., Ogwuegbu, M., Egwurugwu, J.: Heavy metal pollution and human biotoxic effects. Int. J. Phys. Sci. 2 (5): 112-118 (2007)

[9] Espín, S., Martínez-López, E., Jiménez, P., María-Mojica, P., García-Fernández, A.J.: Effects of heavy metals on biomarkers for oxidative stress in Griffon vulture (Gyps fulvus). Environ. Res. 129, 59-68 (2014)

[10] Saha, N., Rahman, M.S., Ahmed, M.B., Zhou, J.L., Ngo H.H., Guo, W.: Industrial metal pollution in water and probabilistic assessment of human health risk. J. Environ. Manage. 185, 70-78 (2017)

[11] Raval, N.P., Shah, P.U., Shah, N.K.: Adsorptive removal of nickel (II) ions from aqueous environment: a review. J. Environ. Manage. 179, 1-20 (2016)

[12] Khan, Z.I., Ahmad, K., Rehman, S., Siddique, S., Bashir, H., Zafar, A., Sohail, M., Ali, S.A., Cazzato, E., De Mastro, G.: Health risk assessment of heavy metals in wheat using different water qualities: implication for human health. Environ. Sci. Pollut. R. 24 (1), 947-955 (2017)

[13] Katsou, E., Malamis, S., Loizidou, M.: Performance of a membrane bioreactor used for the treatment of wastewater contaminated with heavy metals. Bioresource Technol. 102 (6), 4325-4332 (2011) 
[14] Pires, C., Marques, A.P., Guerreiro, A., Magan, N., Castro, P.M.: Removal of heavy metals using different polymer matrixes as support for bacterial immobilisation. J. Hazard. Mater. 191 (1), 277-286 (2011)

[15] Lesmana, S.O., Febriana, N., Soetaredjo, F.E., Sunarso, J., Ismadji, S.: Studies on potential applications of biomass for the separation of heavy metals from water and wastewater. Biochem. Eng. J. 44 (1), 19-41 (2009)

[16] Bilal, M., Shah, J.A., Ashfaq, T., Gardazi, S.M.H., Tahir, A.A., Pervez, A., Haroon, H., Mahmood, Q.: Waste biomass adsorbents for copper removal from industrial wastewater-a review. J. Hazard. Mater. 263, 322-333 (2013)

[17] Abyaneh, A.S., Fazaelipoor, M.H.: Evaluation of rhamnolipid (RL) as a biosurfactant for the removal of chromium from aqueous solutions by precipitate flotation. J. Environ. Manage. 165, 184-187 (2016)

[18] Ahmed, M.J.K., Ahmaruzzaman, M.: A review on potential usage of industrial waste materials for binding heavy metal ions from aqueous solutions. J. Water Process Eng. 10, 39-47 (2016)

[19] Guieysse, B., Norvill, Z.N.: Sequential chemical-biological processes for the treatment of industrial wastewaters: review of recent progresses and critical assessment. J. Hazard. Mater. 267, 142-152 (2014)

[20] Feng, B., Fang, Z., Hou, J., Ma, X., Huang, Y., Huang, L.: Effects of heavy metal wastewater on the anoxic/aerobic-membrane bioreactor bioprocess and membrane fouling. Bioresource Technol. 142: 32-38 (2013)

[21] Tazi-Pain, A., Schrotter, J., Bord, G., Payreaudeau, M., Buisson, H.: Recent improvement of the BIOSEP process for industrial and municipal wastewater treatment. Desalination 146 (1-3), 439-443 (2002)

[22] Aftab, B., Khan, S.J., Maqbool, T., Hankins, N.P.: Heavy metals removal by osmotic membrane bioreactor (OMBR) and their effect on sludge properties. Desalination 403, 117-127 (2017)

[23] Blöcher, C., Bunse, U., Sebler, B., Chmiel, H., Janke, H.D.: Continuous regeneration of degreasing solutions from electroplating operations using a membrane bioreactor. Desalination 162, 315-326 (2004)

[24] Liu, R., Huang, X., Chen, L., Wen, X., Qian, Y.: Operational performance of a submerged membrane bioreactor for reclamation of bath wastewater. Process Biochem. 40 (1), 125-130 (2005)

[25] Petrinić, I., Čurlin, M., Racyte, J., Simonič, M.: Textile wastewater treatment with membrane bioreactor and water re-use. Tekstil: Journal of Textile \& Clothing Technology 58, 11-19 (2009)

[26] Babich, H., Stotzky, G.: Sensitivity of various bacteria, including actinomycetes, and fungi to cadmium and the influence of pH on sensitivity. Appl. Environ. Microbiol. 33 (3), 681-695 (1977)

[27] Nelson, P.O., Chung, A.K., Hudson, M.C.: Factors affecting the fate of heavy metals in the activated sludge process. J. Water Pollut. Control Fed. 53 (8), 1323-1333 (1981) 
[28] Apiratikul, R., Pavasant, P.: Batch and column studies of biosorption of heavy metals by Caulerpa lentillifera. Bioresource Technol. 99 (8), 2766-2777 (2008)

[29] Volesky, B., Holan, Z.: Biosorption of heavy metals. Biotechnol. Prog.11 (3), 235-250 (1995)

[30] Macaskie, L.E., Dean, A.C., Cheetham, A.K., Jakeman, R.J., Skarnulis, A.J.: Cadmium accumulation by a Citrobacter sp.: the chemical nature of the accumulated metal precipitate and its location on the bacterial cells. Microbiology 133 (3), 539-544 (1987)

[31] Aslan, S., Sozudogru, O.: Individual and combined effects of nickel and copper on nitrification organisms. Ecol. Eng. 99, 126-133 (2017) 